\title{
Effect of polluted water on soil and plant contamination by heavy metals in El-Mahla El-Kobra, Egypt
}

\author{
Esawy Kasem Mahmoud ${ }^{1}$ and Adel Mohamed Ghoneim ${ }^{2,3}$ \\ ${ }^{1}$ Soil and Water Sciences Department, Faculty of Agriculture at Tanta, Tanta University, Tanta, Egypt \\ ${ }^{2}$ Soil Science Department, College of Food and Agricultural Sciences, King Saud University, P.O. Box 2460, \\ Riyadh 11451, Saudi Arabia \\ ${ }^{3}$ Agricultural Research Center, Field Crops Research Institute, Rice Research and Training Center, Sakha, \\ Kafr El-Sheikh, 33717, Egypt
}

Correspondence to: Adel Mohamed Ghoneim (aghoneim@ksu.edu.sa)

Received: 24 March 2015 - Published in Solid Earth Discuss.: 8 February 2016

Revised: 19 April 2016 - Accepted: 19 April 2016 - Published: 29 April 2016

\begin{abstract}
The discharge of untreated waste water in Zefta drain and drain no. 5 is becoming a problem for many farmers in the El-Mahla El-Kobra area, Egypt. The discharged water contains high levels of contaminants considered hazardous to the ecosystem. Some plants, soil, water, and sediment samples were collected from the El-Mahla El-Kobra area to evaluate the contamination by heavy metals. The results showed that the heavy metals, $\mathrm{pH}$, sodium adsorption ratio (SAR), biochemical oxygen demand (BOD), and chemical oxygen demand (COD) in the water of Zefta drain and drain no. 5 exceeded permissible limits for irrigation. In rice and maize shoots grown in soils irrigated by contaminated water from Zefta drain and drain no. 5, the bioaccumulation factors for $\mathrm{Cd}, \mathrm{Pb}, \mathrm{Zn}, \mathrm{Cu}$, and $\mathrm{Mn}$ were higher than 1.0. The heavy metals content of irrigated soils from Zefta drain and drain no. 5 exceeded the upper limit of background heavy metals. In this study, the mean contaminant factor values of the drain no. 5 sediments revealed that $\mathrm{Zn}, \mathrm{Mn}, \mathrm{Cu}, \mathrm{Cd}, \mathrm{Pb}$, and $\mathrm{Ni}>6$, indicating very high contamination. The bioaccumulation coefficient values of Cynodon dactylon, Phragmites australis, and Typha domingensis aquatic plants growing in Zefta drain are high. These species can be considered as hyperaccumulators for the decontamination of contaminated water.
\end{abstract}

\section{Introduction}

Contamination of soils by heavy metals, such as $\mathrm{Cd}, \mathrm{Ni}, \mathrm{Zn}$, $\mathrm{Pb}$, and $\mathrm{Cu}$, has increased dramatically during the last few decades (Chibuike and Obiora, 2014) due to mining, smelting, manufacturing, use of agricultural fertilizers and pesticides, municipal waste, traffic emissions, and industrial effluents (Morgan, 2013; Chibuike and Obiora, 2014). Contamination of soils by heavy metals is now widespread (AlNagger et al., 2013). Land degradation caused by heavy metals has significant adverse effects on the environment and ecosystem worldwide (Li et al., 2013; Chen et al., 2015). Dispersion of heavy metals in irrigated soils and the plants that are growing results in the contamination of food that may be hazardous to humans and animals (Jolly et al., 2013). Heavy metals in effluents are poorly soluble in water, and cannot be degraded; they tend to accumulate in soils and subsequently accumulate in plants (Ghoneim et al., 2014). In addition, heavy metals persist in soil which then leach down into the groundwater and may induce enhanced antioxidant enzymatic activities in plants or become adsorbed with solid soil particles (Iannelli et al., 2002). According to Roy and McDonald (2013), carrots grown in soils contaminated by $\mathrm{Cd}$ have the potential to cause toxicological problems in men, women, and young children. Cd uptake by carrot roots was about 5 times more than the regulatory limits for men, 8 times more for women, and 12 times more for children. High levels of $\mathrm{Cd}$ in soil were identified as causing itai-itai disease in Toyama Prefecture, Japan; however, soil solution levels 


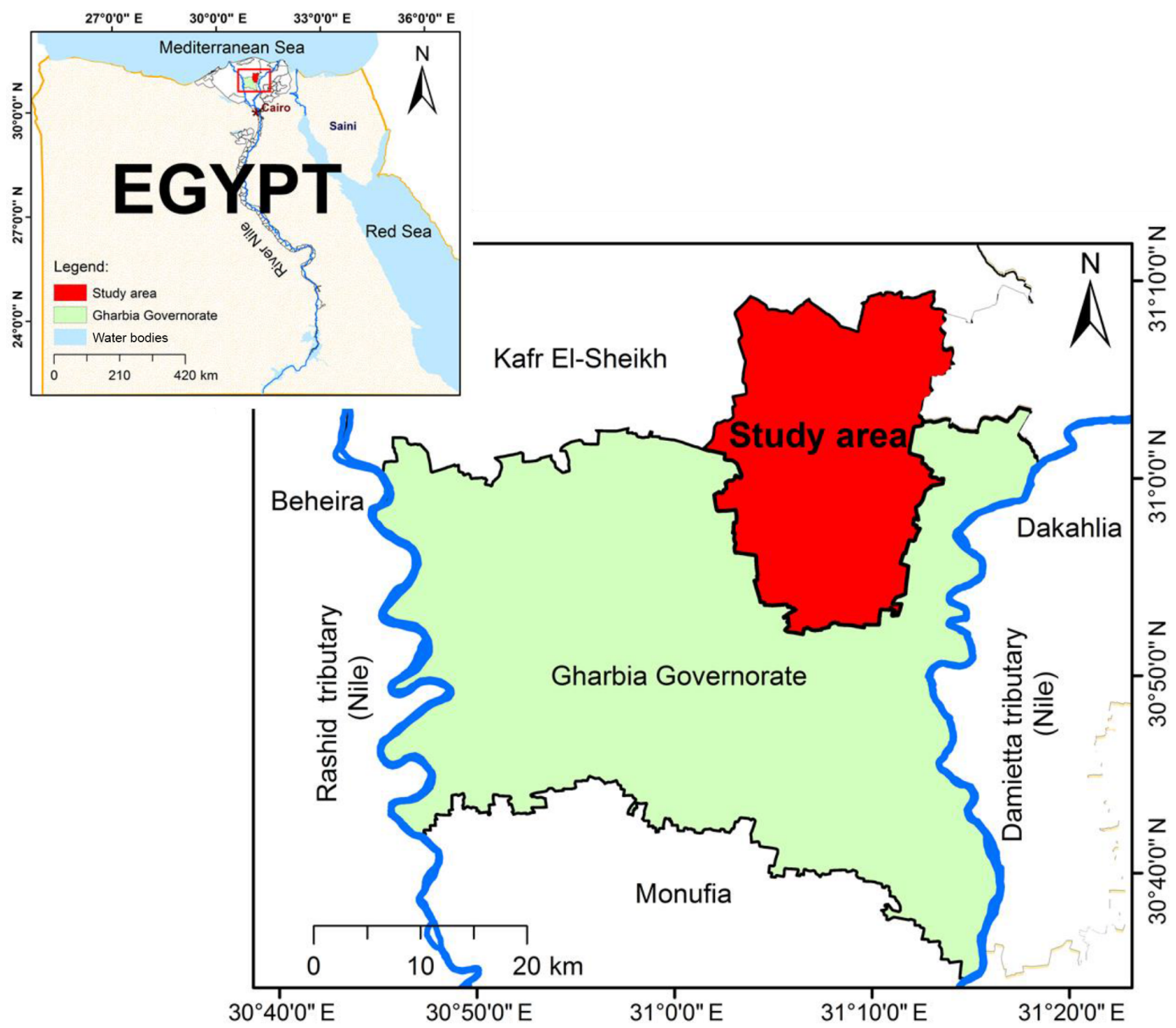

Figure 1. Location of study area.

similarly high in $\mathrm{Cd}$ do not seem to cause health problems for people living in Shipham, England (Morgan, 2013). For the $\mathrm{Cu}$-contaminated soils planted with tomato (Solanum lycopersicum L.), these values would range between 32.9 and $1696.5 \mathrm{mg} \mathrm{kg}^{-1}$, depending on soil properties (Sacristán et al., 2015). Accumulation of toxic heavy metals in living plant cells results in various deficiencies, reduction of cell activities, and inhibition of plant growth (Farooqi et al., 2009).

Transfer of heavy metals from soils to plants is one of the key pathways for exposure of humans via the food chain. In order to assess risks to health associated with metals in soils, it is necessary to predict transfer of heavy metals from soil to tissues of plants for subsequent use in phytoremediation (Roy and McDonald, 2013; Ye et al., 2014). Heavy metal pollution is persistent, covert, and irreversible (Wang et al., 2011). This kind of pollution not only degrades the quality of the food crops, atmosphere, and water, but also threatens the health of human and animals (Dong et al., 2011). Excessive intake of the $\mathrm{Pb}$ to human body can damage the nervous, skeletal, endocrine, enzymatic, circulatory, and immune system (Zhang et al., 2012). The chronic effects of Cd consist of lung cancer, pulmonary adenocarcinomas, prostatic prolifer- ative lesions, kidney dysfunction, bone fractures, and hypertension (Brevik et al., 2015).

Soil is a key part of the Earth system as it control the hydrological, erosional, biological, and geochemical cycles. The soil system also offers goods, services, and resources to humankind (Berendse et al., 2015; Brevik et al., 2015; Decock et al., 2015; Smith et al., 2015). This is why it is necessary to research how soils are affected by societies. Pollution is one of these damaging human activities, and we need more information and assessment of soil pollution (Mahmoud and El-Kader, 2015; Riding et al., 2015; Roy and Mcdonald, 2015; Wang et al., 2015). Soil degradation is now considered a challenge of a global dimension and is included in environmental policy frameworks. A prime example is the United Nations Convention to Combat Desertification (UNCCD), which recognizes the important role of soils in sustainable development and has anticipated the ambitious aim to achieve zero net land degradation by 2030 (UNCCD, 2012). Soils have been used to detect the deposition, accumulation, and distribution of heavy metals in different locations (Alirzayeva et al., 2006; Onder et al., 2007), but little quantitative information is available on the contamination of agri- 
cultural soils in El-Mahla El-Kobra, Egypt, by heavy metals. To close this knowledge gap, this study investigated the contamination of agricultural soil and plants by heavy metals in residential and industrial areas in El-Mahla El-Kobra, Egypt.

\section{Materials and methods}

\subsection{Site description, samples, and analysis}

El-Mahla El-Kobra (Fig. 1) is located at $30^{\circ} 34^{\prime} \mathrm{N}, 30^{\circ} 45^{\prime} \mathrm{E}$. The dominant sources of heavy metal pollution are waste water irrigation, manure, and sediment applications for metallic ores. The El-Mahla El-Kobra area is density populated (4.5 million $462683 \mathrm{~km}^{-2}$ ) and contains 183 industrial factories such as for textiles, food, oil, and other industries. The quantity of industrial and municipal waste water is around $243500 \mathrm{~m}^{3}$ day $^{-1}\left(107500 \mathrm{~m}^{3}\right.$ day $^{-1}$ municipal sewage and $136000 \mathrm{~m}^{3} \mathrm{day}^{-1}$ industrial waste water), which discharges into Zefta drain (flow, $354240 \mathrm{~m}^{3}$ day $^{-1}$ ) and drain no. 5 (flow, $265248 \mathrm{~m}^{3}$ day $^{-1}$ ) without treatment, except $63627 \mathrm{~m}^{3}$ day $^{-1}$ municipal waste water which can be treated at Dawakhlia plant.

Seventy representative soil samples $(0-30 \mathrm{~cm})$ in summer 2012 were collected from cultivated lands of El-Mahla ElKobra, Egypt, which are irrigated with drainage water from Zefta drain and drain no. 5, and 15 samples of soil were collected which is irrigated with water from Baher El Mlah canal (fresh water). The soil samples were air-dried and ground to pass through a $2 \mathrm{~mm}$ screen for chemical analysis. The soils' $\mathrm{pH}$ was determined in a saturated soil paste extract (Richards, 1954). Calcium and magnesium levels were determined titrimetrically using versenate (Jackson, 1973). The level of sodium was determined using a flame photometer (Richards, 1954). The level of total carbonate was determined using the calcimeter as a $\mathrm{CaCO}_{3}$ percentage according to Loeppert and Suarez (1996). The total heavy metals (Cd, $\mathrm{Pb}, \mathrm{Zn}, \mathrm{Fe}, \mathrm{Mn}, \mathrm{Cu}$, and $\mathrm{Ni}$ ) were measured by the atomic absorption spectrophotometer after the soil samples had digested concentrated mixtures of $\mathrm{HNO}_{3}$ and $\mathrm{HClO}_{4}$ acids (Page, 1982). Samples of rice and maize cultivated crops (age 65 days in summer 2012) that are grown in the studied soils, and three other aquatic plant species (Cynodon dactylon, Phragmites australis, and Typha domingensis) which are grown in Zefta drain, were also collected at different times. The plant samples were dried in an oven at $75^{\circ} \mathrm{C}$ for $72 \mathrm{~h}$. The total heavy metals content in plant shoots was measured using the atomic absorption spectrophotometer after the plant samples had digested concentrated $\mathrm{H}_{2} \mathrm{SO}_{4}$ and $\mathrm{H}_{2} \mathrm{O}_{2}$ (Chapman and Pratt, 1961).

\subsection{Transfer of heavy metals}

The bioconcentration factor $(\mathrm{BF})$ of each metal in plants was calculated by dividing the total content in the plants by the total content in soil (Brooks, 1998). In addition, 17 water sam-

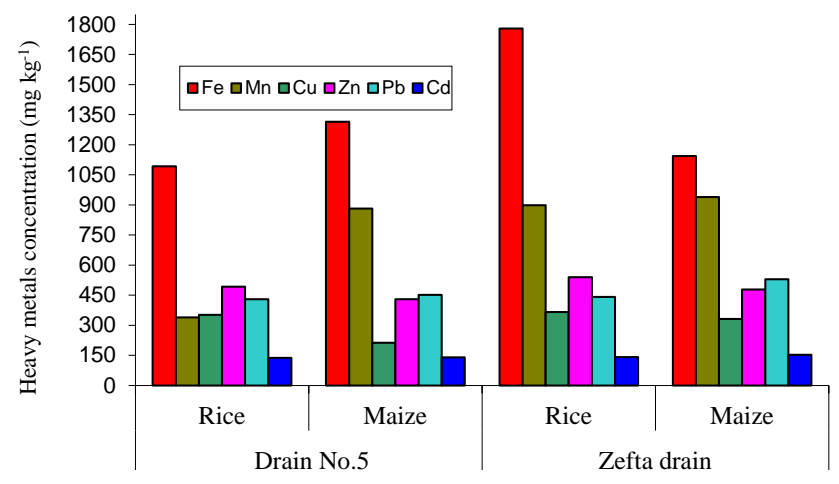

Figure 2. Concentration of heavy metals in maize and rice shoots grown in soils irrigated by water from Zefta drain and drain no. 5 .

ples were collected from Zefta drain and drain no. 5 at different times (March 2012 to March 2013) at about $20 \mathrm{~cm}$ below the water surface and were chemically analysed for $\mathrm{pH}$, electrical conductivity (EC), sodium adsorption ratio (SAR), biological oxygen demand (BOD), chemical oxygen demand (COD), and heavy metals content (APHA, 2005). The bioaccumulation coefficients of each heavy metal in aquatic plants were calculated by dividing the total heavy metal content in aquatic plants by the concentration in water.

The contaminant factor ( $\mathrm{Cf}$ ) for soil is the ratio obtained by dividing the concentration of each heavy metal in the sediment by the background values (Håkanson, 1980).

$\mathrm{Cf}=C_{\text {Heavy metal }} / C_{\text {Background }}$

According to Håkanson (1980), the values of $\mathrm{Cf}<1$ indicate low contamination; $1<\mathrm{Cf}<3$ indicates moderate contamination; $3<\mathrm{Cf}<6$ indicates considerable contamination; and $\mathrm{Cf}>6$ indicates very high contamination.

\section{Results and discussion}

\subsection{Effect of contaminated water on plant and soil contamination}

Heavy metals content was higher in rice and maize shoots grown in the soil around the Zefta drain than the same crops in soil irrigated by water from drain no. 5 (Fig. 2). This was due to the high total heavy metal contents in these soils (Table 1). Maize shoots contained more $\mathrm{Fe}, \mathrm{Cd}, \mathrm{Mn}$, and $\mathrm{Pb}$ than rice shoots, and this may be attributed to the planting of rice under flooded conditions. Under flooded conditions, $\mathrm{Fe}, \mathrm{Cd}, \mathrm{Mn}$, and $\mathrm{Pb}$ could be precipitate as $\mathrm{FeS}_{2}, \mathrm{CdS}, \mathrm{MnS}$, and $\mathrm{PbS}$, respectively, due to the reducing conditions. Heavy metals content in rice and maize shoots exceeded the defined limits reported by Kabata-Pendias and Pendias (1992) and were above the levels acceptable for elemental composition of uncontaminated plant tissue. Alloway (1990) reported that in angiosperms, uncontaminated plant tissue contains 0.64 , 
Table 1. Total concentrations of heavy metals in soils irrigated by contaminated water from Zefta drain, drain no. 5, and Baher El Mlah canal.

\begin{tabular}{llrrrr}
\hline & & \multicolumn{3}{c}{ Surrounding soils } & \\
\cline { 3 - 5 } Parameters & Unit & Drain no. 5 & Zefta drain & Baher El Mlah & $\begin{array}{r}\text { Upper limit of total } \\
\text { heavy metals in soils } \\
\text { (Chen et al., 1992) }\end{array}$ \\
\hline $\mathrm{pH}$ & - & $7.80-8.30$ & $7.80-8.50$ & 7.30 & - \\
$\mathrm{CaCO}$ & & $4.10-8.20$ & $3.28-5.74$ & 4.10 & - \\
$\mathrm{Fe}$ & $\%$ & $1226-4989$ & $1790-4757$ & 933 & - \\
$\mathrm{Zn}$ & $\mathrm{mg} \mathrm{kg}^{-1}$ & $102-187$ & $184-449$ & 54 & 120 \\
$\mathrm{Mn}$ & $\mathrm{mg} \mathrm{kg}^{-1}$ & $341-800$ & $172-853$ & 264 & - \\
$\mathrm{Cu}$ & $\mathrm{mg} \mathrm{kg}^{-1}$ & $82-167$ & $123-386$ & 60 & 35 \\
$\mathrm{Cd}$ & $\mathrm{mg} \mathrm{kg}^{-1}$ & $13-28$ & $21-33$ & 11 & 3 \\
$\mathrm{~Pb}$ & $\mathrm{mg} \mathrm{kg}^{-1}$ & $48-92$ & $55-80$ & 53 & 60 \\
$\mathrm{Ni}$ & $\mathrm{mg} \mathrm{kg}^{-1}$ & $55-133$ & $104-164$ & 31 & 6 \\
\hline
\end{tabular}

2.4, 160 , and $14 \mathrm{mg} \mathrm{kg}^{-1}$ of $\mathrm{Cd}, \mathrm{Pb}, \mathrm{Zn}$, and $\mathrm{Cu}$, respectively. It is clear from Fig. 2 and Table 1 that the concentrations of $\mathrm{Cd}$ in rice and maize shoots are higher than other heavy metals compared with the maximum limits according to Kabata-Pendias and Pendias (1992). Li et al. (1994) found that plants absorb $\mathrm{Cd}$ more readily than other heavy metals and levels are often reached that are hazardous to human health before any stress symptoms appear. Chitdeshwari et al. (2002) reported that the use of sewage water increased the uptake of $\mathrm{Cd}$ and $\mathrm{Cr}$ in Amaranthus crops. Phosphate fertilizers were sources of $\mathrm{Cd}$ used in fertilization of rice and maize plants in this study area. Phosphate fertilizers were even measured to contain $200 \mathrm{mg} \mathrm{Cd} \mathrm{kg}^{-1}$ (Nziguheba and Smolders, 2008). The city of El-Mahla El-Kobra is densely populated and is the capital of the local textile industry. Large amounts of industrial and contaminated water are discharged directly into irrigation canals without treatment, which often contain heavy metals that contribute to metals' enrichment in soil (Fakayode and Onianwa, 2002). In addition, rice and wheat ash fertilization is carried out in El-Mahla ElKobra on a large scale (Abou-Sekkina et al., 2010). Application of ash to agricultural soils contributes significantly to the greater concentration of $\mathrm{Cd}$ in agricultural soil from ElMahla El-Kobra. The higher concentration of Zn observed might be due to abrasion of tyres, barks, and $\mathrm{Zn}$-containing compounds, which are used in some manufactured goods, such as paints, cosmetics, automobile tyres, and batteries (Imperato et al., 2003).

The range of $\mathrm{pH}, \mathrm{EC}$, and heavy metal contents in soil samples which are irrigated by water from Zefta drain, drain no. 5, and Baher El Mlah are compared with background limits (Table 3). The soils irrigated by contaminated water from Zefta drain and drain no. 5 show an increase of soil $\mathrm{pH}$ with comparison to soils irrigated by water from Baher El Mlah (fresh water). Similar results were noticed by Gupta et al. (2010) and Saffari and Saffari (2013), who reported that after irrigation with sewage water, $\mathrm{pH}$ increased signifi-
Table 2. Bioconcentration factors of heavy metals in maize and rice shoots grown in soils irrigated by waste water from Zefta drain, drain no. 5 , and limits of heavy metals.

\begin{tabular}{lrr|rr|r}
\hline & \multicolumn{2}{c|}{ Drain no. 5 } & \multicolumn{2}{c|}{ Zefta drain } & \\
\cline { 2 - 6 } Elements & Rice & Maize & Rice & Maize & $\begin{array}{r}\text { Limits of heavy } \\
\text { metals }^{1} \mathrm{mg} \mathrm{kg}^{-1}\end{array}$ \\
\hline $\mathrm{Fe}$ & 0.29 & 0.35 & 0.54 & 0.34 & - \\
$\mathrm{Mn}$ & 3.40 & 2.97 & 1.71 & 1.51 & $300-500$ \\
$\mathrm{Cu}$ & 0.59 & 1.54 & 1.75 & 1.83 & $20-100$ \\
$\mathrm{Zn}$ & 2.82 & 1.71 & 1.44 & 1.32 & $100-400$ \\
$\mathrm{~Pb}$ & 6.73 & 6.83 & 5.26 & 5.66 & $30-300$ \\
$\mathrm{Cd}$ & 6.14 & 6.45 & 6.55 & 2.26 & $5-30$ \\
\hline
\end{tabular}

${ }^{1}$ Kabata-Pendias and Pendias (1992).

cantly. The reason for an increasing soil $\mathrm{pH}$ may be attributed to high $\mathrm{pH}$ values in Zefta drain and drain no. 5 (Table 3). The soils irrigated by contaminated water from Zefta drain and drain no. 5 affect the total dissolved solids (TDSs) (Table 3). Indeed, in comparison to soils which are irrigated by water from Baher El Mlah, the TDS value is greater in Zefta drain and drain no. 5. These results were in agreement with Mollahoseini (2013) and Khaskhoussy et al. (2013), who reported that irrigating with sewage water increased soil salinity, exchangeable $\mathrm{Na}, \mathrm{K}, \mathrm{Ca}, \mathrm{Mg}$, and available P. In general, the concentrations of heavy metals in soils irrigated by water from Zefta drain and drain no. 5 exceeded the upper background limit of total heavy metals (Chen et al., 1992). Contents of $\mathrm{Mn}, \mathrm{Cd}$, and $\mathrm{Ni}$ in soils at Zefta drain were higher than in soils at drain no. 5 , due to the high concentration of heavy metals in Zefta drain water (Table 3). The level of heavy metals of soils irrigated by water from Zefta drain and drain no. 5 was higher than the levels of the surrounding soils of Baher El Mlah canal. Similar results were reported by Chen et al. (1992), who found high levels of heavy metals in soils which are irrigated by polluted industrial waste water. These results coincided with El-Gendi et al. (1997) who indi- 
cated that irrigating sandy soil in the Abou-Rawash area with drainage water increased total $\mathrm{Cu}, \mathrm{Zn}$, and $\mathrm{Fe}$, which reached 125,170 , and 5 times that of the virgin soil in the same area. Both $\mathrm{Cd}$ and $\mathrm{Pb}$ levels in soils measured during this study were higher than those reported by Nassef et al. (2006) and Suciu et al. (2008). These differences might be related to different anthropogenic activities and concentrations of urbanization at each site.

\subsection{Bioconcentration factors (BFs)}

The BF values in the rice and maize shoots are presented in Table 2 . In rice and maize grown in soils irrigated by water from Zefta drain and drain no. 5, the BF values for $\mathrm{Cd}$, $\mathrm{Pb}, \mathrm{Zn}, \mathrm{Cu}$, and $\mathrm{Mn}$ were higher than 1 . This indicates that bioconcentrations of $\mathrm{Cd}, \mathrm{Pb}, \mathrm{Cu}$, and $\mathrm{Mn}$ were high in the plants studied. Fe was an exception because its BF value was lower than 1, indicating low accumulation in studied plants. The $\mathrm{BF}$ values for $\mathrm{Zn}$ and $\mathrm{Cu}$ of rice shoots were higher than maize shoots grown in the same soils irrigated by water from Zefta drain and drain no. 5. These concentrations were attributed to using $\mathrm{ZnSO}_{4}$ as $\mathrm{Zn}$ fertilizer in rice cultivation. Zhao et al. (2010) reported that BF values tend to decrease with increasing soil heavy metal concentration, and values lower than 0.20 are considered normal when plants are grown on polluted soils (McGrath and Zhao, 2003). The differences in the obtained $\mathrm{BF}$ values depend on the heavy metals and the plant species. The higher BF value for $\mathrm{Cd}$ indicates that $\mathrm{Cd}$ accumulated in rice and maize shoots. These differences might be related to heavy metal-binding capacity to roots (Toth et al., 2009), available metals, interactions between physicochemical parameters, and the plant species grown in these soils (Bose and Bhattacharyya, 2008).

\subsection{Quality of drainage water}

Concentrations of BOD and COD ranged from 442 and 978 to 632 and $2445 \mathrm{mg} \mathrm{L}^{-1}$ in Zefta drain, while the BOD and COD value ranged from 540 and 882 to 723 and $2301 \mathrm{mg} \mathrm{L}^{-1}$ in drain no. 5 (Table 3). This water would be classified as high strength (Metcalf and Eddy, 2003). These results were in agreement with Pescond (1992), who reported that chemical properties of water include total dissolved solids (TDSs); BOD and COD showed higher values in untreated sewage water compared to groundwater. The BOD / COD ratio in Zefta drain and drain no. 5 ranged from 0.25 and 0.31 to 0.45 and 0.61 , respectively. The waste water with a BOD / COD ratio below 0.50 contains some toxic components such as dyes and heavy metals (Linsley et al., 1992).

The average TDSs was 1016 in drain no. 5, 1130 in Zefta drain, and $334 \mathrm{mg} \mathrm{L}^{-1}$ in Baher El Mlah canal. The SARs in water of Zefta drain and drain no. 5 were above 12, which is considered a potential level for aggregate slaking, soil swelling, and clay dispersion, and thus reduction in hydraulic

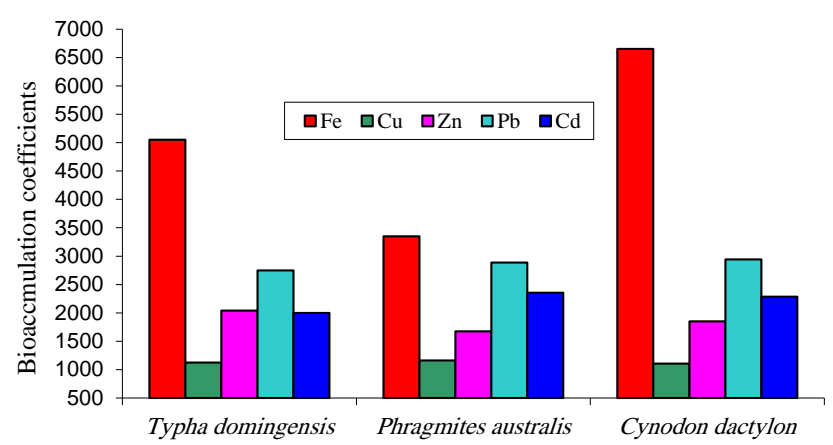

Figure 3. Bioaccumulation coefficients of heavy metals in Typha domingensis, Phragmites australis, and Cynodon dactylon plants grown in Zefta drain.

conductivity (Mace and Amrhein, 2001). The heavy metals in the two drains were higher than in the water of Baher El Mlah canal which could be attributed to discharge of industrial waste water into the two drains without treatment. The level of heavy metals exceeded the criteria limits for irrigation water (FAO, 2010; E.C.S, 48/1992). Similar results reported by Matloub and Mehana (1998) showed that sewage often has high values of temperature, $\mathrm{pH}$, hardness, alkalinity, COD, TDS, $\mathrm{NO}_{3}^{-}, \mathrm{NO}_{2}^{-}, \mathrm{Na}, \mathrm{K}, \mathrm{Ca}$, and $\mathrm{Mg}$. Chitdeshwari et al. (2002) reported that increased levels of sewage water increased the uptake of $\mathrm{Cd}$ and $\mathrm{Cr}$ in Amaranthus crops.

\subsection{Heavy metal concentrations in sediments}

The high heavy metal concentrations in sediments of drain no. 5 (Table 4) can be attributed to higher $\mathrm{pH}$ in water which can form ions of insoluble precipitates. The measured concentrations of heavy metals are higher than US Environmental Protection Agency (EPA) toxicity values (US EPA, 1999). Similar findings were reported by Thuy et al. (2007) who found that heavy metals in sediments of five canals which received untreated industrial waste water exceeded the US EPA toxicity levels. The partitioning of heavy metals between sediment and water can be expressed by distribution coefficient ( $\mathrm{Kd}$ ) values $\left(\mathrm{L} \mathrm{kg}^{-1}\right) . \mathrm{Kd}$ values of sediment samples were the highest for $\mathrm{Zn}, \mathrm{Cd}$, and $\mathrm{Mn}$, and lowest for $\mathrm{Pb}, \mathrm{Cu}$, and $\mathrm{Ni}$. The higher $\mathrm{Kd}$ value indicates that the sorption of heavy metals by sediments was strong (Salomons and Forstner, 1980). Sediments are both carriers and potential sources of contaminants in aquatic systems, and these materials also affect groundwater quality and agricultural products when disposed of on land. In this study, the mean $\mathrm{Cf}$ values of the drain no. 5 sediments revealed that $\mathrm{Zn}, \mathrm{Mn}, \mathrm{Cu}$, $\mathrm{Cd}, \mathrm{Pb}$, and $\mathrm{Ni}>6$, indicating very high contamination due to the direct discharge of waste water from the residential and industrial areas. 
Table 3. The chemical analysis of water collected from the Zefta drain, drain no. 5, and Baher El Mlah canal.

\begin{tabular}{llllll}
\hline Parameters & Units & Drain no. 5 & Zefta drain & $\begin{array}{l}\text { Baher El } \\
\text { Mlah }\end{array}$ & $\begin{array}{l}\text { Water criteria for } \\
\text { irrigation water }\end{array}$ \\
\hline $\mathrm{pH}$ & - & 9.80 & 12.2 & 7.20 & $6.5-8.4$ \\
$\mathrm{TDS}$ & $\mathrm{mg} \mathrm{L}^{-1}$ & 1016 & 1130 & 334 & 2000 \\
$\mathrm{SAR}$ & - & 17.3 & 18.2 & 6.00 & $6-12$ \\
$\mathrm{BOD}$ & $\mathrm{mg} \mathrm{L}^{-1}$ & $540-723$ & $442-632$ & 0.00 & 40 \\
$\mathrm{COD}$ & $\mathrm{mg} \mathrm{L}^{-1}$ & $882-2301$ & $978-2445$ & 0.00 & 601 \\
$\mathrm{Fe}$ & $\mathrm{mg} \mathrm{L}^{-1}$ & 0.09 & 0.56 & 0.01 & 5.0 \\
$\mathrm{Zn}$ & $\mathrm{mgL}^{-1}$ & 0.02 & 0.037 & 0.00 & 2.00 \\
$\mathrm{Mn}$ & $\mathrm{mgL}^{-1}$ & 0.68 & 2.91 & 0.03 & 0.20 \\
$\mathrm{Cu}$ & $\mathrm{mg} \mathrm{L}^{-1}$ & 0.15 & 0.28 & 0.12 & 0.20 \\
$\mathrm{Cd}$ & $\mathrm{mgL}^{-1}$ & 0.03 & 0.07 & 0.001 & 0.01 \\
$\mathrm{~Pb}$ & $\mathrm{mg} \mathrm{L}^{-1}$ & 1.05 & 0.18 & 0.05 & 5.00 \\
$\mathrm{Ni}$ & $\mathrm{mgL}^{-1}$ & 0.12 & 0.31 & 0.02 & 0.20 \\
\hline
\end{tabular}

${ }^{1}$ Egyptian Chemical Standards (48/1992)

Table 4. Average heavy metal concentrations, contaminant factor, and distribution coefficients $(\mathrm{Kd})$ in sediments of drain no. 5 compared with toxicological reference values (US EPA, 1999).

\begin{tabular}{llrrr}
\hline Element & $\begin{array}{l}\text { Conc. }\left(\mathrm{mg} \mathrm{kg}^{-1}\right) \\
\text { mean } \pm \mathrm{SD}\end{array}$ & $\mathrm{Et}$ & $\mathrm{Cf}$ & $\mathrm{Kd}\left(\mathrm{L} \mathrm{kg}^{-1}\right)$ \\
\hline $\mathrm{Zn}$ & $647.5 \pm 36.7$ & 110 & 6.25 & 32375.0 \\
$\mathrm{Mn}$ & $2125.0 \pm 74.3$ & - & 12.7 & 3125.0 \\
$\mathrm{Cu}$ & $425.0 \pm 12.4$ & 16 & 4.25 & 2833.3 \\
$\mathrm{Cd}$ & $97.5 \pm 4.6$ & 0.6 & 9.55 & 3250.0 \\
$\mathrm{~Pb}$ & $145.0 \pm 4.5$ & 31 & 4.80 & 138.10 \\
$\mathrm{Ni}$ & $195.0 \pm 9.8$ & - & 7.33 & 1625.0 \\
\hline
\end{tabular}

Et: US EPA toxicity reference value; Cf: contaminant factor; Kd: distribution coefficients $\left(\mathrm{L} \mathrm{kg}^{-1}\right)$.

\subsection{Bioaccumulation coefficients of aquatic plants}

The bioaccumulation coefficients of heavy metals in plants of Cynodon, dactylon, Phragmites australis, and Typha domingensis grown in Zefta drain are shown in Fig. 3. The bioaccumulation coefficients of metals in Cynodon dactylon were higher than in Phragmites australis and Typha domingensis. These plant species can be considered as hyperaccumulators, and are used for the decontamination of contaminated water. The use of plants for decontamination of polluted waters has been described as rhizofiltration (Brooks, 1998). The three species would be useful for phytoremediation of contaminated water in a particular area. Bonanno (2013) showed that Phragmites australis and Typha domingensis species may be used as biomonitors of trace element contamination in sediment. Overall, $T$. domingensis and $P$. australis showed a greater capacity of bioaccumulation as well as a greater efficiency of element removal than A. donax. In particular, T. domingensis and P. australis may be used for Hg phy- tostabilization; the former also acted as a hyperaccumulator for trace elements' phytoextraction and phytostabilization. In contaminated wetlands, the presence of $T$. domingensis and $P$. australis may increase the general retention of trace elements. Wafaa et al. (2010) demonstrated that Phragmites australis and Tamarix aphllya species are significant as vegetation filters and for cleaning the soils from contamination by heavy metals by phytoextraction. Antioxidant thiol compounds were probably involved in the mechanisms used by $P$. australis to alleviate metal toxicity. As $P$. australis is considered suitable for phytostabilizing metal-contaminated sediments, understanding its tolerance mechanisms to toxic metals is important to optimize the conditions for applying this plant in phytoremediation (Rocha et al., 2014).

\section{Conclusions}

Delta drains often receive high amounts of organic and inorganic pollutants from industrial and domestic waste water as well as diffuse agricultural drainage. High priority should be given to Zefta drain and drain no. 5 sites which receive high loads of pollutants. This was confirmed by the lower water quality and soils polluted by heavy metals in the El-Mahla El-Kobra area. Industrial and municipal waste water sources in El-Mahla El-Kobra area must be treated before being discharged in Zefta drain and drain no. 5. Using agricultural soils contaminated by heavy metals in the cultivation of rice and maize crops for human consumption may result in health hazards. 
Acknowledgements. The authors appreciate and thank the College of Food and Agricultural Sciences, Research Center, and Deanship of Scientific Research, King Saud University, Saudi Arabia, for the financial support of this research study. We also acknowledge Tanta University, governorate of Tanta, Egypt, for the funds and support in carrying out this research.

Edited by: A. Cerdà

\section{References}

Abou-Sekkina, M. M., Issa, R. M., Bastawisy, A. E., and El-Helece, W. A.: Characterization and evaluation of thermodynamic parameters for Egyptian heap fired rice straw ash (RSA), Int. J. Chem., 2, 81-88, 2010.

Alirzayeva, E. G., Shirvani, T. S., Yazici, M. A., Alverdiyeva, S. M., Shukurov, E. S., Ozturk, L., Ali-Zade, V. M., and Cakmak, I.: Heavy Metal accumulation in Artemisia and Foliaceous Lichen species from the Azerbaijan flora, Forest Snow and Landscape Research, 80, 339-348, 2006.

Alloway, B. J.: Heavy Metals in Soils, John Wiley \& Sons, Inc. New York, ISBN 0470215984, 1990.

Al Naggar, Y. A., Naiem, E. A., Seif, A. I., and Mona, M. H.: Honey bees and their products as a bio-indicator of environmental pollution with heavy metals, Mellifera, 13, 10-20, 2013.

APHA, AWWA and WEF: Standard methods for the examination of water and wastewater, XX Edn., American Public Health Association, Washington, DC, 2005.

Berendse, F., van Ruijven, J., Jongejans, E., and Keesstra, S.: Loss of plant species diversity reduces soil erosion resistance, Ecosystems, 18, 881-888, 2015.

Bonanno G.: Comparative performance of trace element bioaccumulation and biomonitoring in the plant species Typha domingensis, Phragmites australis and Arundo donax, Ecotox. Environ. Safe, 97, 124-130, 2013.

Bose, S. and Bhattacharyya, A. K.: Heavy metal accumulation in wheat plant grown in soil amended with industrial sludge, Chemosphere, 70, 1264-1272, 2008.

Brevik, E. C., Cerdà, A., Mataix-Solera, J., Pereg, L., Quinton, J. N., Six, J., and Van Oost, K.: The interdisciplinary nature of SOIL, SOIL, 1, 117-129, doi:10.5194/soil-1-117-2015, 2015.

Brooks, R.: Plants that hyper accumulated heavy metals CAB international, London, UK, 1998.

Chapman, H. D. and Pratt, P. F.: Methods of Analysis for Soils, Plant and Water, Univ. of California, Division of Agric. Sci., USA, Chapter 2, 56-64, 1961.

Chen, X. W., Tsz-Fung Wong, J., Mo, W. Y., Man, Y. B., Wang-Wai $\mathrm{Ng}$, C., and Wong, M. H.: Ecological Performance of the Restored South East New Territories (SENT) Landfill in Hong Kong (2000-2012), Land Degrad. Dev., 1, 1-13, doi:10.1002/ldr.2366, 2015.

Chen, Z. S., Lee, D. Y., Wong, D., and Wang, Y.: Effect of various treatments on the uptake of $\mathrm{Cd}$ from polluted soils by vegetable crops, in: Proceedings of 3rd work shop of soil pollution and prevention, National Chuny-Hsing University Taiwan, ROC, 277-292, 1992
Chibuike, G. U. and Obiora, S. C.: Heavy Metal Polluted Soils: Effect on plants and bioremediation methods, Appl. Environ. Soil Sci., 12 pp., doi:10.1155/2014/752708, 2014.

Chitdeshwari, T., Savithri, P., and Mahimai Raja, S.: Effect of sewage bio-solids compost on biomass yield of Amaranths and heavy metal availability, J. Indian Soc. Soil Sci., 50, 480-484, 2002.

Decock, C., Lee, J., Necpalova, M., Pereira, E. I. P., Tendall, D. M., and Six, J.: Mitigating $\mathrm{N}_{2} \mathrm{O}$ emissions from soil: from patching leaks to transformative action, Soil, 1, 687-694, 2015.

Dong, J., Yang, Q. W., Sun, L. N., Zeng, Q., Liu, S. J., and Pan, J.: Assessing the concentration and potential dietary risk of heavy metals in vegetables at a $\mathrm{Pb} / \mathrm{Zn}$ mine site, China, Environ. Earth Sci, 64, 1317-1321, 2011.

Egyptian Chemical Standards: Protection of the Nile River and water stream from pollution, Ministry of Irrigation, Cairo, Egypt, low No. 48/1992.

El-Gendi, S. A., Badawy, S. H., and Helal, M. I.: Mobility of some heavy metal nutrients in sandy soils irrigated with sewage effluent, J. Agric. Sci. Mansoura Univ., 22, 3535-3552, 1997.

Fakayode, S. and Onianwa, P.: Heavy metal contamination of soil and bioaccumulation in Guinea grass (Panicum maximum) around Ikeja industrial estate, Lagos, Nigeria. Enviro., Geology, 43, 145-150, 2002.

FAO.: The wealth of waste: The economics of wastewater use in agriculture, in: FAO Water Report No. 35, Water Development and Management Unit, Food and Agriculture Organization of the United Nations, ISBN 978-92-5-106578-5, 2010.

Farooqi, Z. R., Iqbal, M. Z., Kabir, M., and Shafiq, M.: Toxic effects of lead and cadmium on germination and seedling growth of Albezia lebbeck (L.) Benth, Pak, J. Bot. 41, 27-33, 2009.

Ghoneim, A. M., Al-Zahrani, S., El-Maghraby, S., and Al-Farraj, A.: Heavy metal distribution in Fagonia indica and Cenchrus ciliaris native vegetation plant species, J. Food Agric. Environ., 12, 320-324, 2014.

Gupta, S., Satpati, S., Nayek, S., and Garai, D.: Effect of wastewater irrigation on vegetables in relation to bioaccumulation of heavy metals and biochemical changes, Environ. Monit. Assess., 165, 169-177, 2010.

Håkanson, L.: Ecological risk index for aquatic pollution control: sediment logical approach, Water Res., 14, 975-1001, 1980.

Hernandez, T., Moreno, J., and Costa, F.: Influence of sewage sludge application on crop yields and heavy metal availability, Soil Sci. Plant Nutr., 37, 201-210, 1991.

Iannelli, M.A., Pietrini, F., Flore, L., Petrilli, L., and Massacci, A.: Antioxidant response to cadmium in Phragmites australis plants, Plant Physiol. Biochem., 40, 977-982, 2002.

Imperato, M., Adamo, P., Naimo, D., Arienzo, M., Stanzione, D., and Violante, P.: Spatial distribution of metals in urban soils of Naples city (Italy), Environ. Poll., 124, 247-256, 2013.

Jackson, M. L.: Soil Chemical Analysis, Constable and Company Ltd, London, 1973.

Jolly, Y. N., Islam, A., and Akbar, S.: Transfer of metals from soil to vegetables and possible health risk assessment, Springer Plus, 2, 1-8, 2013.

Kabata-Pendias, A. and Pendias, H.: Trace Elements in Soils and Plants, Boca Raton, FL: CRC Press, 1992.

Khaskhoussy, K., Hachicha, M., Kahlaoui, B., Messoudi-Nefzi, B., Rejeb, A., Jouzdan, O., and Arselan, A.: Effect of treated 
wastewater on soil and corn crop in the Tunisian area, J. Appl. Sci. Res., 9, 132-140, 2013.

Li, G. C., Haw-Tarn, L., and Chi-Sen, L.: Uptake of heavy metals by plants in Taiwan, paper from conference title: Biogeochemistry of trace elements, Environ. Geochem. Hlth., 2, 153-160,1994.

Li, X. L., Gao, J., Brierley, G., Qiao, Y. M., Zhang, J., and Yang, Y. W.: Rangeland degradation on the Qinghai-Tibet Plateau: implications for rehabilitation, Land Degrad. Dev., 24, 72-80, 2013.

Linsley, R. K., Joseph, B., Franzini, D. L., and Freyberg, G. T.: Water Resources Engineering, Fourth Edn., McGraw-Hill, Inc., New York, 1992.

Loeppert, R. H. and Suarez, D. L.: Carbonate and gypsum, in: Methods of Soil Analysis, edited by: Sparks, D. L., Part3, SSSA Book Ser. 5., SSSA, Madison, WI, 437-474, 1996.

Lone, M. I. and Rizwan, M.: Evolution of industrial effluents for irrigation and their effect on soil and chemical properties, in: Proc. NSMTCC 97, Environ. Poll., Islamabad, Pakistan, 30, 269-280, 1997.

Mace, J. E. and Amrhein, C.: Leaching and reclamation of a soil irrigated with moderate SAR waters, Soil Sci. Soc. Am. J., 65, 199-204, 2001.

Mahmoud, E. and Abd El-Kader, N.: Heavy metal immobilization in contaminated soils using phosphogypsum and rice straw compost, Land Degrad. Dev., 26, 819-824, 2015.

Matloub, M. A. and Mehana, T. A.: Utilization of treated sewage effluent for reclaiming a salt-affected soil, Egypt, J. Appl. Sci., 13, 298-316, 1998.

McGrath, S. P. and Zhao, F. J.: Phytoextraction of metals and metalloids from contaminated soils, Current Opinion in Biotechnology, 14, 277-282, 2003.

Metcalf and Eddy (Eds.): Wastewater Engineering: Treatment, Disposal, Reuse, 4th Edn., McGraw-Hill, Inc. New York, 2003.

Mollahoseini, H.: Long term effects of municipal wastewater irrigation on some properties of a semiarid region soil of Iran, Int. J. Agr. Plant Pro., 4, 1023-1028, 2013.

Morgan, R.: Soil, heavy metals, and human health, in: Soils and human health, edited by: Brevik, E. C. and Burgess, L. C., Boca Raton, FL, USA, CRC Press, 59-82, 2013.

Nassef, M., Hannigan, R., EL Sayed, K. A., and Tahawy, M. S.: Determination of some heavy metals in the environment of Sadat industrial city, Proceedings of the 2nd Environmental Physics Conference, 14-152, 2006.

Nziguheba, G. and Smolders, A.: Inputs of trace elements in agricultural soils via phosphate fertilizers in European countries, Sci. Total Environ., 390, 53-57, 2008.

Onder, S., Dursun, S., Gezgin, S., and Demirbas, A.: Determination of Metal Pollution in Grass and Soil of City Centre Green Areas (Konya, Turkey), Polish J. Environ. Studies, 16, 145-154, 2007.

Page, M. A. (Ed.): Methods of soil analysis, Part 2, Academic press, New York, 1982.

Pescod, M. B.: Wastewater treatment and use in agriculture, Bull FAO 47, 125, Rome, Italy, 1992.

Richards, R. L.: Diagnosis and improvement of saline and alkali soils, USDA, Agriculture Handbook, No. 60US Gov., Printing office Washington, 1954.

Riding, M. J., Martin, F. L., Jones, K. C., and Semple, K. T.: Carbon nanomaterials in clean and contaminated soils: environmental implications and applications, SOIL, 1, 1-21, doi:10.5194/soil1-1-2015, 2015.
Rocha, A. S., Marisa, R., Almeidab, M., Clara, P., Bastoa, M., and Teresa, S. D.: Antioxidant response of Phragmites australis to $\mathrm{Cu}$ and Cd contamination, Ecotox. Environ. Safe., 109, 152-160, 2014.

Roy, M. and McDonald, L. M.: metal uptake in plants and health risk assessments metal-contaminated smelter soils, Land Deg. Dev., 26, 785-792, doi:10.1002/ldr.2237, 2013.

Roy, M. and Mcdonald, L. M.: Metal uptake in plants and health risk assessments in metal-contaminated smelter soils, Land Degrad. Dev., 26, 785-792, 2015.

Sacristán, D., Peñarroya, B., and Recatalá, L: Increasing the knowledge on the management of $\mathrm{Cu}$-contaminated agricultural soils by cropping tomato (Solanum Lycopersicum L.), Land Degrad. Dev., 26, 587-595, doi:10.1002/ldr.2319, 2015.

Saffari, V. R. and Saffari, M.: Effect of treated municipal wastewater on bean growth, soil chemical properties, and chemical fractions of zinc and copper, Arab. J. Geol. Sci., 6, 4475-4485, 2013.

Saleemi, M. A.: Environmental assessment and management of irrigation and drainage scheme for sustainable agriculture growth, Environ. Protection Agency Bull., (Lahore), 64 pp., 1993.

Salomons, W. and Forstner, V.: Trace metal analysis on pollution sediments 11, Evaluation of environmental impact Environ, Technol. Lett., 1, 506-517, 1980.

Salwa, F. Shalaby, E., Bahy, A., and El Deen, A.: Water management problems associated with urban sprawl in Gharbia Governorate, Egypt using remote sensing and GIS, Int. J. Adv. Rem. Sens. \& GIS, 2, 243-259, 2013.

Smith, P., Cotrufo, M. F., Rumpel, C., Paustian, K., Kuikman, P. J., Elliott, J. A., McDowell, R., Griffiths, R. I., Asakawa, S., Bustamante, M., House, J. I., Sobocká, J., Harper, R., Pan, G., West, P. C., Gerber, J. S., Clark, J. M., Adhya, T., Scholes, R. J., and Scholes, M. C.: Biogeochemical cycles and biodiversity as key drivers of ecosystem services provided by soils, SOIL, 1, 665685, doi:10.5194/soil-1-665-2015, 2015.

Suciu, I. C., Cosma, M., Todic, S. D., Bolboac, S. D., and Jantschi, L.: Analysis of soil metal pollution and pattern in central Transylvania, Int. J. Molecul. Sci., 9, 434-453, 2008.

Thuy, L. T., Nguyen, N. V., and Tu, T. L.: Anthropogenic input of selected heavy metals $(\mathrm{Cu}, \mathrm{Cr}, \mathrm{Pb}, \mathrm{Zn}$ and $\mathrm{Cd})$ in aquatic sediments of Hochiminh city, Vietnam, 2007.

Toth, T., Tomas, J., Lazor, P., Bajcan, D., and Jomova, D.: The Transfer of metals from contaminated soils into agricultural plants in high Tatars region, Czech J. Food Sci., 27, 390-393, 2009.

UNCCD: Zero net land degradation: A sustainable development goal for Rio C20, Bonn, Germany, United Nations Convention to Combat Desertification, 2012.

US Environmental Protection Agency: Screening level ecological risk assessment protocol for hazardous waste combustion facilities, Vol. 3, Appendix E: Toxicity reference values, EAP530D99-001C, 1999.

Wafaa, A., Al-Taisan, A. A., Al-Qarawi, A., and Moodi, S.: Effect of water stress by polyethylene glycol 8000 and sodium chloride on germination of Ephedra Alata Decne seeds, Biol Sci. J., 17, 253-257, 2010.

Wang, H.-Q., Zhao, Q., Zeng, D.-H., Hu, Y.-L., and Yu, Z.-Y.: Remediation of a magnesium-contaminated soil by chemical amendments and leaching, Land Degrad. Dev., 26, 613-619, 2015. 
Wang, M., Song, H., Chen, W., Lu, C., Hu, Q., and Ren Z.: Cancer mortality in a Chinese population surrounding a multi-metal sulphide mine in Guangdong province: an ecologic study, BMC Public Health, 16, 319, doi:10.1186/1471-2458-11-319, 2011.

Ye, M., Sun, M., Liu, Z., Ni, N., Chen, Y., Gu, C., Kengara, F. O., Li, H., and Jiang, X.: Evaluation of enhanced soil washing process and phytoremediation with maize oil, carboxymethylcyclodextrin, and vetiver grass for the recovery of organochlorine pesticides and heavy metals from a pesticide factory site, J. Environ. Manage., 141, 161-168, 2014.
Zhang, H., Lin, Y. H., Zhang, Z., Zhang, X., Shaw, S. L., Knipping, E. M., Weber, R. J., Gold, A., Kamens, R. M., and Surratt, J. D.: Secondary organic aerosol formation from methacrolein photooxidation: Roles of $\mathrm{NO}_{x}$ level, relative humidity, and aerosol acidity, Environ. Chem., 9, 247-262, 2012.

Zhao, K., Liu, X., Xu, J., and Selim, H.: Heavy metal contaminations in a soil - rice system: identification of spatial dependence in relation to soil properties of paddy fields, J. Hazard Mater., 181, 778-787, 2010. 